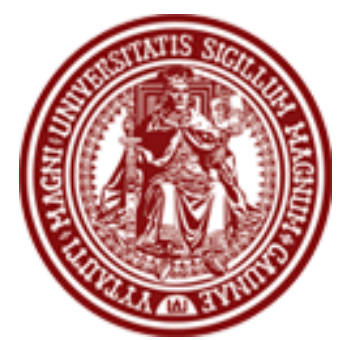

DE DE GRUYTER OPEN $\mathbf{U}$

\section{BALTIC JOURNAL OF LAW \& POLITICS}

A Journal of Vytautas Magnus University

VOLUME 7, NUMBER 2 (2014)

ISSN 2029-0454

\title{
IS THE CZECH REPUBLIC ON ITS WAY TO SEMI-PRESIDENTIALISM?
}

\author{
Vít Hloušek \\ Associate Professor \\ Masaryk University, Faculty of Social Sciences (Czech Republic) \\ Contact information \\ Address: Jostova 10, 60200 Brno, Czech Republic \\ Phone: +420549 494761 \\ E-mail address: hlousek@fss.muni.cz
}

Received: October 10, 2014; reviews: 2; accepted: December 23, 2014.

\begin{abstract}
The main aim of the article is to contribute to the bourgeoning debate on semipresidentialism, its definition, and its characteristic features, with analysis of the empirical example of the Czech Republic, a country which, according to Elgie's standard definition, shifted to semi-presidentialism in 2012. The author investigates whether and how Miloš Zeman, the first directly elected president of the Czech Republic, influences relations among the key political institutions in the direction of the model of a semi-presidential democracy. The paper sets out the working concept of semi-presidentialism first and, through the lenses of process tracing, analyses the goals and acts of Zeman after he entered office in January 2013. The case study of the Czech Republic sheds light not only on the recent development(s) in the Czech political system, but it can be seen as an interesting example of how strong political personalities are attempting to expand their influence on politics in a parliamentary democracy and what the possible limits of this effort are.
\end{abstract}




\section{KEYWORDS}

Czech Republic, semi-presidentialism, parliamentary democracy, Miloš Zeman 
"I suppose that the Czech Social Democratic Party should work towards the next Czech president [...] to be firstly the symbol of Czech statehood, to express the political will of government and the Parliament, not to be their opponent. [...] The president should be at the same time a moderator, not demiurge, of dialogue among the parliamentary political parties, a mediator of conflicts, not their producer. And there is one thing a president should never do: create parties of The Castle from factions inside the established political parties close to The Castle [...]" (Miloš Zeman, April 2001).

"President, especially a president elected by direct election by the citizens for five years, must not consider the actual moods and mood swings of particular political parties" (Miloš Zeman, May 2013).

\section{INTRODUCTION}

The concept of semi-presidentialism is by far the most frequently discussed part of what Cheibub calls "the most influential tripartite distinction" including parliamentary and presidential democracies. ${ }^{1}$ There are two basic reasons for this. First, the concept covers a steadily increasing number of empirical cases of the regimes that are floating between the two classical categories. Second, the concept of semi-presidentialism is still a challenging one, in the sense of seeking for precise definition and a firm set of criteria. The general theoretical discussion concerns especially the criterion of direct elections of a head of state as a focal point for turning from parliamentary to a semi-presidential type. Theoretical arguments must, however, be confronted with empirical evidence and especially with those country case studies that offer diachronic comparison of fully parliamentary and (potentially) semi-presidential cases. One of the cases that challenges the view that a mere change of direction of an election automatically means a shift in regime type is the Czech Republic-the case analysed in this paper.

The evidence from other Central and Eastern countries shows that directly elected presidents, albeit operating in the political systems of parliamentary democracies with still less embedded informal constitutional conventions delimiting the role of leading political institutions and actors, are sometimes prone to challenge the existing balance of powers and prerogatives in their favour. Frances Millard ${ }^{2}$ analysed regular clashes between the president and prime minister in the case of Poland and she demonstrated how important the political personality of a

1 José Antonio Cheibub, Zachary Elins, and Tom Ginsburg, "Beyond Presidentialism and Parliamentarism," British Journal of Political Science Vol. 44, No. 3 (2014): 515 // DOI: $10.1017 /$ S000712341300032X.

2 Frances Millard, "Presidents and Democratization in Poland: The Roles of Lech Wałesa and Aleksander Kwaśniewski in Building a New Polity," Journal of Communist Studies and Transition Politics Vol. 16, No. 3 (2000). 
president is. Alenka Krašovec and Damjan Lajh ${ }^{3}$ demonstrated in the Slovenian case that even in the situation of a president endowed only with minor powers by the constitution, a strong and ambitious personality holding the office can considerably increase the role of president in the political life of the country. The Czech Political system seems to be close to the Slovenian case, since introduction of direct election of the head of state without increasing his or her powers in the same time. Miloš Zeman, one of the top Czech politicians of the 1990s era, has been demonstrating strong political ambitions and a willingness to be a very active head of the state ever since he announced his run for the Czech presidency. His election could pave the way for changing the Czech political system from parliamentary democracy to a semi-presidential model.

The recent holder of the Czech presidential office, Miloš Zeman, has been elected directly by the country's citizens for the first time in the history of the Czech Republic. There have been many attempts to introduce direct election for the head of the Czech state. The debate concerning direct elections has been re-emerging ever since the adoption of the Czech constitution in December 1992. ${ }^{4}$ The amendment of the constitution and related constitutional law were approved in the rather hectic atmosphere of late 2011 and early 2012, so the elections in January 2013 could be conducted on a universal and popular basis. ${ }^{5}$ Miloš Zeman has emerged through tough competition as the winner, thus continuing the previous tradition of strong and experienced political personalities holding office. After Václav Havel and Václav Klaus, Zeman is the third strong political personality willing to leave a visible imprint on the functioning of the office and someone who is "a usual suspect" in terms of attempts to increase the political role of the president to the detriment of constitutional conventions established during the previous two decades of the development of the Czech political system.

The main aim of the article is to discuss the importance of formal and informal factors in the definition of a semi-presidential political system. The second aim of the paper is to assess whether the Czech Republic is undergoing a change of political system from a parliamentary to a semi-presidential model of democracy.

To achieve the aforementioned goals, the paper will proceed as follows. First, the debate on the concept of semi-presidential political systems must be addressed in order to demonstrate a certain plurality of approaches to defining the basic features of such a regime. Next the article discusses the influences of the

\footnotetext{
3 Alenka Krašovec and Damjan Lajh, "The Chameleonic Character of the Slovenian Presidents of the Republic"; in: Vít Hloušek, ed., Presidents above parties? Presidents in Central and Eastern Europe, Their Formal Competencies and Informal Power (Brno: muni press, 2013).

${ }^{4}$ See Markéta Musilová and Jakub Šedo, "Diskuse o zavedení přímé volby prezidenta v České republice a její schválení": 13, 22-30; in: Jakub Šedo, ed. České prezidentské volby v roce 2013 (Brno: Centrum pro studium demokracie a kultury, 2013).

${ }^{5}$ Ibid. : 31-35.
} 
constitutional framework delimiting presidential powers and position vis-à-vis other key political institutions. The article addresses the role of the Czech and even Czechoslovak political and historical tradition as well, since it frames a picture of a president as a sort of strong statesperson and even moral arbiter who should stay above the political parties and who is seen by the people as a safeguard of the democratic development of the country. Subsequently, the analysis of important moments in post-January 2013 development must be provided in order to show whether we can confirm the rising influence and power of the president over other key political institutions. The next part of the analysis of important political events is an assessment of the goals Zeman established and the roles he played in these events. Zeman's role in establishing a caretaker cabinet in 2013 is briefly compared with the previous interventions of Havel and Klaus into the process of government formation.

\section{THE CONCEPT OF SEMI-PRESIDENTIALISM AS A PART OF THE} PROBLEM

The concept of semi-presidentialism was born shortly after the consolidation of the political system of the Fifth French Republic. The famous French scholar Maurice Duverger coined a concept of semi-presidentialism that consisted of three main features: (1) president elected by universal suffrage, (2) president endowed with quite considerable powers, and (3) president who constitutes together with the government an executive body dependent on the support of parliament. ${ }^{6}$ While the first and the third criteria are clear enough the second one requires clarification. What exactly does it mean to have considerable powers?

A very useful summary of the debate started by flaws in the original Duverger concept was provided by Robert Elgie. ${ }^{7}$ For Elgie the root of the problem is the same as for us: in the vagueness of the criterion that within the framework of semipresidentialism a president must possess "quite considerable powers". What exactly that encompasses is difficult to define. Elgie resolved the issue by focussing on constitutional criteria, defining semi-presidentialism as a combination of a directly elected president with a government dependent on parliamentary support: "A semipresidential regime may be defined as the situation where a popularly elected fixed-

\footnotetext{
6 Maurice Duverger, "A New Political System Model: Semi-Presidential": 142; in: Arend Lijphart, ed., Parliamentary versus Presidential Government (Oxford: Oxford University Press, 1992).

7 Robert Elgie, "The Politics of Semi-Presidentialism": 1-12; in: Robert Elgie, ed., Semi-Presidentialism in Europe (Oxford: Oxford University Press, 1999).
} 
term president exists alongside a prime minister and cabinet who are responsible to parliament." ${ }^{8}$

Elgie's concept has one important advantage. It is a clearly defined concept with a set of criteria that can simply be applied and assessed. However, it still has some problems concerning the application as well as internal clarity. Let us take the Czech Republic as an example. In 2012, the change of constitution introduced the direct election of the head of state. No other important shifts concerning duties and powers were made, the mutual positions of the government and the President and President towards the parliament have remained the same. According to Elgie, the Czech Republic simply shifted from a parliamentary to a semi-presidential democracy. It should imply an increasing role of the president in political life and, as we will demonstrate, attempts to "accrue" more power occurred several times since January 2013. However, such attempts occurred during the period of both indirectly elected presidents as well. The only difference is the new legitimization of such activities by the claim of direct legitimacy of the president by the citizens' vote. This was obviously missing in Havel's and Klaus's rhetoric.

We have to also consult the volume edited by Robert Elgie and Sophia Moestrup ${ }^{9}$ devoted solely to the phenomenon of mezzo regimes in post-communist countries. In the volume, the ambiguous nature of semi-presidentialism in the above-presented definition is, however, shown by case studies as well as in the distinction between "highly presidentialised semi-presidentialism and the balanced presidential-prime ministerial semi-presidentialism" as two facets of a semipresidential system. The authors are absolutely right in showing that the neither "pure" parliamentary democracy nor "pure" presidential systems encompass the whole reality of post-communist institutional choices. However, the concept is stretched too much to go into the matter further.

We can therefore conclude that while Elgie certainly solved one of the issues raised by Duverger's concept, he in fact foregrounded another and perhaps comparable one. This begs the question: what do these political systems with directly elected presidents and a cabinet dependent on parliament have in common? Given the large number of states which are semi-presidential, according to Elgie's definition ${ }^{10}$, does the problem of their mutual incompatibility as systems, which was already present in Duverger's examples, increase significantly? Several

8 Ibid.: 13; see also Robert Elgie, "Semi-presidentialism: An Increasingly Common Constitutional Choice": 3; in: Robert Elgie, Sophia Moestrup, and Yu-Shan Wu, eds., Semi-Presidentialism and Democracy (Basingstoke: Palgrave MacMillan, 2011).

9 Robert Elgie and Sophia Moestrup, eds., Semi-Presidentialism in Central and Eastern Europe (Manchester: Manchester University Press, 2008).

${ }^{10}$ Robert Elgie, supra note 7: 14. 
other definitions of semi-presidentialism have been attempted ${ }^{11}$ but semipresidentialism as a kind of mezzo category remains a very problematic one because it usually creates a temptation to "stretch" the concept too far. ${ }^{12}$

Other authors, such as Alan Siaroff, attempted to deal with the conceptual problems of semi-presidentialism by eliminating this model of political system as such. Siaroff correctly argues that existing debate on semi-presidential government produced a concept based on constitutional criterion which is "of varying utility in telling us about the powers of presidents"13. He suggested replacing the mezzo category of semi-presidentialism with different variants of parliamentary government in which a president can play dominant, corrective, or merely figurehead roles. Siaroff is absolutely right stressing the role of power analysis for general evaluation of the nature of given political systems. His measurement of presidential powers is however based prevalently on definition of presidential prerogatives in constitution and does not pay particular attention to informal execution of political powers beyond the strictly legal limits.

We are not going to solve the problem in general. The case study of contemporary relations between President Zeman and other political institutions in the Czech Republic, however, requires some working concept of semipresidentialism as a type of political system different from a parliamentary democracy to see whether the Czech Republic shifts from the later type to the former.

We can start with Elgie's definition and shed more light on the relation of president and government, which seems to be the most important problem. According to our working definition, semi-presidentialism consists of three elements: (1) directly elected head of state, (2) the government responsible to the parliament (or more precisely to its lower chamber, the house of deputies, in the Czech case), and (3) the president must have a real impact on the composition of the government and its agenda. ${ }^{14}$ This condition is not fulfilled only when such a

11 For example José Antonio Cheibub, Presidentialism, Parliamentarism and Democracy (Cambridge: Cambridge University Press); Gianfranco Pasquino, "Semi-presidentialism: A Political Model at Work," European Journal of Political Reasearch Vol. 31, No. 1 (1997) // DOI: 10.1111/1475-6765.00309; Giovanni Sartori, Comparative Constitutional Engineering: An Inquiry into Structures, Incentives and Outcomes (Basingstoke: MacMillan, 1994); André Krouwel, "Measuring presidentialism of Central and Eastern European Countries," Working Papers Political Science (Amsterdam: Vrije Universiteit) No. 02/2003 // http://www.fsw.vu.nl/en/Images/Globalisation,\%20Neoliberalism\%20and\%20the\%20Employment\%20Question_tcm31-42728.pdf; Thomas Sedelius and Sten Berglund, "Towards Presidential Rule in Ukraine: Hybrid regime Dynamics under Semi-Presidentialism," Baltic Journal of Law \& Politics Vol. 5, No. 1 (2012).

12 On concept stretching see Giovanni Sartori, "Concept Misformation in Comparative Politics," The American Political Science Review Vol. 64, No. 4 (1970) // DOI: 10.2307/1958356.

13 Alen Siaroff, "Comparative presidencies: The inadequacy of the presidential, semi-presidential and parliamentary distinction," European Journal of Political Research Vol. 42, No. 3 (2003): 309 // DOI: 10.1111/1475-6765.00084.

${ }^{14}$ I owe thanks for inspiration to the interesting paper of André Krouwel, supra note 11: 4-5, who defined the semi-presidential system among other features by the fact that the president in such a system has "substantive executive prerogatives" but the governmental power still prevails. Giovanni 
power is written into the constitution; but, we have to analyse relations between the president and the government in the period of government creation, personnel changes in its composition and in the moment of drafting or modifying the crucial points of the governmental agenda. We are aware of the limits of such an incremental approach based on a single case study and we are perfectly understand the limits of this working definition for any kind of generalization. However, the combination of research methods described in the following part and this working definition creates a credible and heuristically sound framework for the case study of the Czech Republic after the first direct election of the head of state.

Such a working concept does not entirely put aside problems related to the former Duverger definition. The notion of "real impact on composition of government and its agenda" is only a bit clearer than "considerable powers". Still, to operationalize "real impact" is easier than "considerable powers" since we do know what kind of powers and activities are considered as the most important for building the president's position in the political system. To achieve the "real power", a president must have:

(1) formal power to nominate and dismiss the government,

(2) formal or informal influence on the process of government composition (directly or indirectly via consultations with a designated prime minister), and

(3) formal or informal impact on the agenda of the government.

\section{DATA AND METHODS}

The following analysis provides a qualitative single case study of the Czech Republic in the period between January 2012 and March $2014^{15}$ aimed at providing a deep understanding of the nature of political change caused by the introduction of direct elections of president and the consequences this change might have on the nature of the Czech political system. The main aim of the study is to examine in depth a single case study of a potentially changing political system with the main purpose being to analyse and explain unique features of selected events in Czech politics relevant to the aforementioned working concept of semi-presidentialism. The case study has the potential to be used as arguments for a broader discussion on semi-presidentialism as a distinctive type of political system. However, the this article's comparative ambitions are only of secondary importance. ${ }^{16}$

Sartori (supra note 11 , p. 132) prefers to talk about "dual authority structure" within the executive body.

${ }^{15}$ At the beginning of 2012, Zeman confirmed that he would be a candidate for Czech president. In March 2014, his first year in office was completed.

16 See James Mahoney, "Qualitative Methodology and Comparative Politics," Comparative Political Studies Vol. 40, No. 2 (2007): 126-128 // DOI: 10.1177/0010414006296345 for a general discussion on the role of qualitative studies for building concepts in social sciences. 
It is of utmost importance to analyse a selection of events in order to explain what is happening with the Czech political system and the role played by President Zeman in Czech politics since January 2013. According to our view, with respect to the previous section and its findings, the political clashes involving Zeman have been included on one hand, and other main institutions such as the government and/or the parliament on the other hand. We decided to exclude clashes with other institutions or actors for reasons related to the length and scope of the paper. However, we can at least mention here some important events of high symbolical meaning, such as disputes over nominations of professors at Czech universities (May 2013) and the right to grant an individual pardon (November 2013). Both of these are prerogatives of the president according to the constitution and other laws. However, Zeman declared that he is not going to grant any general amnesty in the future and that he will not in fact grant individual pardons either which is a policy he has executed ever since his introduction to office. According to the law on tertiary education in the Czech Republic, the process of a university professor's nomination is crowned with a ceremonial appointment by the president. President Zeman refused to nominate one of the candidates in the spring of 2013 ; and, as a consequence of heated debates between him and the majority of Czech academia, he declared that no new professors would be nominated in the future. Such examples illustrate well the form of "independence" with which Zeman interprets the legal boundaries and obligations related to the execution of the office of Czech head of state.

The given criteria led to institutional clashes in the course of specific events: nomination of Czech envoy to Slovakia (March 2013), nomination of Rusnok's cabinet (June 2013), nomination of Sobotka's cabinet after the early elections in October 2013 as well as the performance of the Party of Citizens' Rights "Zemanites" in this election.

In order to analyse these events, the methodological tool used here is the process tracing method, which aims at showing causal mechanisms of analysed processes. ${ }^{17}$ As we understand the entire activity of Zeman in the office of President as a process with still unclear results (continuity of a parliamentary system or semipresidential turn) we cannot apply the methods of process tracing strictly. We can however draw inspiration from this method in the sense that we need to analyse carefully any event we take into consideration and look especially for the outcome

17 Derek Beach and Rasmus Brun Pedersen, Process-Tracing Methods: Foundations and Guidelines (Ann Arbor: The University of Michigan Press, 2003); Jeffrey T. Checkel, "Process Tracing"; in: Audie Klotz and Deepa Prakash, eds. Qualitative methods in international relations: a pluralist guide (London: Palgrave Macmillan, 2008). 
of the event from the point of view of a persistent or changing power equilibrium between the president and other institutions.

\section{THE ROLE OF THE CZECH POLITICAL TRADITION}

To understand one important undertone of the Czech political debate concerning the role and function of a president in Czech politics, one must take into account the path dependency of contemporary debate on the periods in office of two predecessors of Zeman - Václav Klaus and Václav Havel. An important source of understanding is also the tradition of the concept of presidency as a kind of political and especially moral leadership as established by the first president of interwar Czechoslovakia Tomáš Garrigue Masaryk (in office since 1918 till 1934).

Contrary to the fact that the Czechoslovak constitution of 1920 framed the Czechoslovak political system as a parliamentary democracy following in effect the model of the French Third Republic, Masaryk was able to play a very important political role. This was thanks to his moral authority, aureole of "the President Liberator," as well as his political skills and contacts with influential parts of the Czech political, economic, and cultural elite. He not only warranted Czech democratic development but also played the role of a patriotic symbol. He was able to increase his political capacity as well by building a block of like-minded politicians and the so-called Cast/e ${ }^{18}$ became recognized as one of the centres of political power. The most important part of Masaryk's legacy consists, however, of the popular image of a strong and active president who was seen by the people as a kind of moral authority contrasting with the image of common politicians who were often seen as incompetent and corrupt.

The same dichotomy between the moral authority of the president and other politicians sometimes resonated in the case of Václav Havel as well. Havel tried many times to use his given moral supremacy to oppose solutions fostered by other politicians, however, without much success in the end. Yet, Havel succeeded in opposing the attempts of leaders of two of the then strongest parties - Civic and Social Democrats - Miloš Zeman and Václav Klaus to contain his political role and to turn him into a mere "wreath layer". ${ }^{19}$

Symptomatic for further development is the clear discrepancy between the objectives and performance of Klaus once he became President. Klaus declared dispersing with the concept of presidency as conducted and advocated by Havel. Especially during his second period in office (2008-2013), Klaus tried to accrue

\footnotetext{
${ }^{18}$ A name derived from the symbol of the seat of the Czechoslovak / Czech president at Prague Castle.

19 Lubomír Kopeček and Josef Mlejnek, "Different Confessions, Same Sins? Václav Havel and Václav Klaus as Czech Presidents": 38-42, 46-57; in: Vít Hloušek, ed. Presidents above parties? Presidents in Central and Eastern Europe, Their Formal Competencies and Informal Power (Brno: muni press, 2013).
} 
political power and to also change the constitutional convention limiting presidential powers. He tried to "push the limits" of some nominated functions (such as the reluctance to nominate new judges automatically), he tried to introduce and decide on some important issues related to the policy of the Czech Republic towards European integration (such as the process of ratification of the Lisbon Treaty etc.). ${ }^{20}$ On the other hand, Klaus was more self-restrained in relation to processes of government formation compared to Havel's effort to influence the composition and agenda of the cabinet.

Generally however, both Havel and Klaus tried to play an active role and to conceptualize the position of president as a strong political institution with a high level of symbolic as well as some level of real political power. They basically succeeded in the long term perspective to maintain the high status of the office in public eyes. ${ }^{21} \mathrm{~A}$ combination of this heritage and the direct method of election almost certainly could have paved the way for a semi-presidential turn.

\section{A CONSTITUTIONAL DEFINITION OF THE PRESIDENTIAL OFFICE - A TEXT WITH POLYSEMOUS CONNOTATIONS}

The introduction of direct presidential elections in 2012 was not connected with any other change of the position of president in the Czech constitutional system, and neither was it accompanied by any expansion of presidential competencies. The prerogatives and powers of the president have remained untouched since the adoption of the new Czech constitution in December 1992.

According to the constitution of the Czech Republic (articles 62 and 63), the president of the Czech Republic has some important competences in relation to both government and the parliament. The list of the competencies is presented in the following table.

Table 1. Selected competencies of the Czech president ${ }^{22}$

\begin{tabular}{|l|l|}
\hline $\begin{array}{l}\text { Competencies } \\
\text { related } \\
\text { government }\end{array}$ to & $\begin{array}{l}\text { appoint and recall the Prime Minister and [according to prime } \\
\text { minister's proposal] other members of the Government and } \\
\text { accept their resignation, recall the Government and accept its } \\
\text { resignation } \\
\text { authorize the Government the resignation of which the }\end{array}$ \\
\hline
\end{tabular}

20 Jan Kysela and Zdeněk Kühn, "Presidential Elements in Government: The Czech Republic," European Constitutional Law Review Vol. 3, No. 1 (2007): 102-111 // DOI: 10.1017/S1574019607000910.

${ }^{21}$ It is important to stress the long-term perspective since the performance of both Havel and Klaus at the end of their second terms was far from being widely accepted. Klaus's amnesty declared in January 2013 even led to him being accused of high treason.

${ }_{22}$ Source: Constitution of the Czech Republic, Art. 62, 63 and 64; italics indicates that the competence is executed only with authorisation by a countersignature of the prime minister or a member of government. 


\begin{tabular}{|c|c|}
\hline & $\begin{array}{l}\text { President has accepted or which he has recalled to execute their } \\
\text { office temporarily until a new Government is appointed of the } \\
\text { Supreme Court } \\
\text { - negotiate and ratify international treaties; he may delegate } \\
\text { the negotiation of international treaties to the Government or, } \\
\text { subject to the Government consent, to its individual members } \\
\text { - President of the Republic has the right to attend meetings of } \\
\text { the Government, to ask for reports from the Government and its } \\
\text { members, and to discuss with the Government or its members } \\
\text { the issues that are in their competence. }\end{array}$ \\
\hline $\begin{array}{l}\text { Competences } \\
\text { related to the } \\
\text { Parliament }\end{array}$ & $\begin{array}{l}\text { - convene [constitutive] sessions of the Chamber of Deputies } \\
\text { - dissolve the Chamber of Deputies [cannot act on his / her own } \\
\text { will, however] } \\
\text { - have the right to return to the Parliament an enacted law with } \\
\text { the exception of Constitutional Acts [suspensive veto only easy to } \\
\text { be voted down by the House of Deputies] } \\
\text { - sign enacted laws } \\
\text { - call elections to the Chamber of Deputies and the Senate } \\
\text { - President of the Republic has the right to attend meetings of } \\
\text { both the Chambers of the Parliament, their Committees and } \\
\text { Commissions. He shall be given the floor whenever he asks for it. }\end{array}$ \\
\hline
\end{tabular}

The list of competencies contains exact quotations from the constitution in order to highlight one important feature of the basic Czech document. Many of president's prerogatives are declared in a very general and vague way. Let us take the nomination process for the prime minister and government. Theoretically, the president can appoint to this function any single person possessing the legal capacity. ${ }^{23}$ There are neither substantive nor time limits, so the president can "take time" before the decision concerning the candidate for a prime minister is made. The members of government shall be nominated as suggested by the prime minister but the text of the constitution is unclear about deadlines and any particular provisions concerning this process. We will see that exactly these features of the Czech constitution were used by Zeman, who tried to extend the reading of the constitution as much as possible (contrary to constitutional conventions and the traditions of Czech politics since Havel's and Klaus' periods) to intervene in the composition of the cabinet.

Some doubts about the nature of the Czech political systems were raised even before the change of the indirect to direct method of election. Jan Kysela and

${ }^{23}$ There is one limit given by Art. 68 of the Czech constitution: the president has only two attempts, if both of his nominees fail to get a parliamentary vote of confidence, the third person to create the government is appointed by the chair of the house of deputies of the Czech parliament. 
Zdeněk Kühn, Czech experts in constitutional law, ${ }^{24}$ discussed the question of the precise type of Czech political system and came to the conclusion that the Czech Republic is a parliamentary democracy according to its constitution as well as according to political praxis. However, they analysed examples of how both Havel and Klaus tried to enhance the political role of the president and concluded with the warning that a combination of the "flexible" delimitation of the president's prerogatives and direct elections could lead to semi-presidentialisation in Czech politics. $^{25}$

\section{ZEMAN IN ACTION: ATTEMPTS TO "ACCRUE" MORE PERSONAL POWER}

To weaken or even shake the position of the centre-right Nečas cabinet was the aim of the most important messages delivered by Zeman to Czech citizens during the campaign before the presidential election. The first opportunity to contest the government emerged as early as in March 2013 and it was connected with the question of the nomination of the new Czech envoy to Moscow and to Bratislava. At the end of March 2013, Zeman declared that he would gladly appoint the wife of Václav Klaus Livia for the position of Czech ambassador to Bratislava. Regardless of the officially presented reasons, it could be seen as a kind of thank you to Klausová for her support of Zeman in the campaign. ${ }^{26}$ Later on, Zeman declared that he supported the nomination of former Czech astronaut and communist MEP Vladimír Remek for the same position to Moscow. Both of these nominations were crushed on the refusal of the minister of foreign affairs, Schwarzenberg, who clearly stated that these two people were not professional diplomats and he would never nominate them. ${ }^{27}$ The dispute over these two persons expanded soon to a general "war" between Zeman and Schwarzenberg that practically paralysed the process of ambassador circulation including some political nominations in favour of people close to government parties. Schwarzenberg refused to nominate Klausová and Remek and Zeman refused to appoint any other candidate. Both parts of the dispute used arguments by which the adversary

\footnotetext{
24 Jan Kysela and Zdeněk Kühn, supra note 20.

25 Such flexibility was used as powerful rhetorical device by Zeman as well. Commenting upon the fact that many of routines of behaviour of the Czech head of state is not fixed by constitution but by constitutional conventions, Zeman said: "Above all I would like to say that the notion of a constitutional convention is completely idiotic because in the case that it was a constitutional convention, it would be anchored in the constitution in some way. These are nothing more than conventions. The president, albeit directly elected, cannot change the constitution but he has of course sovereign right to change the conventions that are not anchored in the constitution" (Právo (July 11, 2013) // http://www.zemanmilos.cz/cz/clanky/----rozhovor-prezidenta-republiky-pro-denik-pravo.htm).

${ }^{26}$ Livia Klausová criticized the wife of Karel Schwarzenberg for the sake of her Austrian nationality and for the fact that she does not speak Czech which fostered a lot of chauvinistic argument against Schwarzenberg as a candidate not patriotic enough and obliged to serve foreign interests.

27 The president can appoint only the people who are nominated by the MFA.
} 
disregarded constitutional conventions. Schwarzenberg accused Zeman of trying to "introduce the customs that are pretty close to the presidential system" 28 and the personal dispute between Zeman and Schwarzenberg was transformed into an institutional clash between the president and government at the end of April 2014. The stalemate, however, lasted until the fall of Nečas's cabinet and Zeman proved that he could involve an important and symbolically relevant part of government and that this involvement matters a lot. From the perspective of a common Czech citizen, the envoy question was not that important and both Zeman and Schwarzenberg could be perceived as trouble-makers. Generally, this affair did not damage Zeman's reputation and he could look for a new challenge in order to increase his political power.

The fall of the cabinet led by Petr Nečas in June 2013 brought an excellent opportunity in this respect. The notoriously unstable coalition government composed of the Civic Democratic Party (ODS), Tradition-Responsibility-Prosperity Party (TOP 09) and minor Liberal Democratic Party (LIDEM) was shaken by a political scandal concerning the Prime Minister Nečas. On the night of June 12, police raided the government offices and took into custody some top ODS politicians, state officials and the prime minister's secretary Jana Nagyová. The resignation of Nečas and the entire cabinet opened a window of opportunity for President Zeman since parliamentary clubs were divided on the opinion of whether to continue the coalition without Nečas or whether to approach the early elections soon.

The ODS, TOP 09 and LIDEM declared that they still had 101 chairs in the house of deputies and they could create a new government on the same platform of coalition cooperation. The Social Democrats, Communist and Public Affairs Party claimed early elections as the only reasonable solution. Miloš Zeman was the politician who could tip the scale at that moment.

Facing the claims of leaders of three prospective coalition parties to form a new cabinet, Zeman returned once again to the rhetoric of stopping Nečas's government saying repeatedly: "I do not want to have Nečas's cabinet without Nečas". Such a position was perfectly in line with Zeman's strategy in the electoral campaign when he stressed being the left-wing candidate and built an important part of his strategy on attacking the cabinet. On June 24, 2013, Zeman declared that he would charge independent Jiři Rusnok with the formation of the new cabinet which should be the "cabinet of experts" with an aim to rule until the regular election in May 2014 or at least to early election in the case that the house of

28 Schwarzenberg: Musím se ozvat, když se Zeman pokouší zavádět moresy prezidentského system, Právo (April 6, 2013). 
deputies should decide on its own dissolution. Rusnok, the former minister of finance of Zeman's cabinet in 2001-2002 (and minister of industry and commerce in Špidla's cabinet in 2002-2003), was labelled as a well-respected person, professional, and an economic expert and Zeman did not forget to stress that the government "[m]ust not inevitably have a political mandate exactly because it is going to be a cabinet of experts." 29 After a brief prevarication by Rusnok and Zeman, Rusnok was officially confirmed by Zeman as the designated prime minister a day later.

It is important to stress that Zeman's nomination was made against the will of most of the parliamentary parties. There was a deal among parties of the former coalition cabinet to form a new one with sufficient support in the house of deputies. The Czech Social Democratic Party was split on this issue and the chairman especially, Bohuslav Sobotka, did his best to avoid Rusnok's semi-political cabinet composed of political friends of the president. There was no reason to think that the chances of Rusnok creating a cabinet to be supported by the parliament were high. The Social Democrats and Communist Party were much more concerned with finding the shortest way to an early election which they hoped to win, in the case of the former, and to score very well in in the case of the later party, with a stronger growing vision to form a left-wing coalition government after the early election. Zeman's vision of a "cabinet of experts" was evaluated by main parties as an attempt to push the limits of presidential power in order to gain direct control over the cabinet. The objective of creating a cabinet of Zeman's political allies and friends was disapproved by neither Zeman nor Rusnok, just on the contrary. In his first interview as prime minister, Rusnok responded to the objection that he was going to form a cabinet of the president's friends as follows: "[...] I do not mind that someone labels us as friends because I think that it is better to rule with friends and people able to deal with each other on a good interpersonal base $[\ldots]^{\prime \prime} .30$

ODS and TOP 09 politicians reacted with accusations of "Putinization" of Czech politics, shift to presidential regime, and violation of the constitution. Social Democrats reacted with a growing intraparty feud. Sobotka's wing was trying to downplay Zeman's influence on Czech politics fearing that Rusnok would create the cabinet composed of people who would help the "Zemanites" party in the next parliamentary election and damage electoral returns for the Czech Social Democracic Party. Many top Social Democrats criticised the fact that some former or active members of the Czech Social Democratic Party should be among Rusnok's ministers. An opponent faction led by the head of the southern Moravian regional

\footnotetext{
${ }^{29}$ Zeman odkryl karty, chce úřednickou vládu, Právo (June 24, 2013).

30 Rozhovor s Jiř́m Rusnokem, českým premiérem, Radiožurnál (June 26, 2013) // http://www.podcasty.info/katalog/ranni-interview-26-06-2013-07-50.html.
} 
government, Michal Hašek, tried to convince the mainstream that it is necessary and advantageous to cooperate with Zeman and to support Rusnok's cabinet. Sobotka even tried to play the card of claiming the chance to be designated himself after the supposed failure of Rusnok's team to get the vote of confidence. Finally, however, Sobotka lost the intraparty battle and the Communists decided to support Rusnok relatively soon after negotiating with him on the preliminary agenda of the cabinet. The same applied for the Public Affairs Party. ${ }^{31}$

In the meantime, Rusnok proceeded quickly with the task of composing the cabinet. He was not only backed by Zeman, but was, at the moment of designation, assessed relatively positively by the citizens as well. According to an opinion poll for Czech TV, half of the respondents agreed with Rusnok's nomination. ${ }^{32}$ The rhetoric of the caretaker government of experts which would fight the economic crisis and stop some of the most unpopular austerity measures paid off. The popular mood, however, changed once the composition of the new team was finally set. Some names in particular raised doubts, such as close political ally to Zeman, Martin Pecina (minister of the interior), controversial former CEO of Czech TV, Jiří Balvín (minister of culture), and especially the minister of finance Jan Fischer, who was former prime minister of a semi-political cabinet in the period 2009-2010. Fischer ran unsuccessfully for the presidential office in 2013 and he was unable to pay campaign debts in the total sum of circa 200.000 Euro. After being nominated to the new cabinet, the money "miraculously" appeared in his presidential account.

Zeman's attempt to negotiate support for Rusnok's cabinet with the parliamentary clubs also resulted in mixed results. Besides this, he tried as much as possible to obstruct the chances of the former coalition returning to power. Moreover, he attempted to get 101 signatures certified by a public notary in the case that he would nominate a government after the potential failure of Rusnok's turn. At the same time, he "impartially" threatened the Social Democrats by declaring that in such a case, he could nominate only some informateur instead of designating the new prime minister or he could give Rusnok a second chance. ${ }^{33}$

The vote of confidence on August 7, 2013, was a failure for Rusnok. 93 deputies supported the cabinet, 100 deputies voted against it. After two weeks, the house of deputies decided on its dissolution and opened the way for early election. Zeman authorised Rusnok's cabinet to continue its executive functions until the

31 The Public Affairs Party was a minor protest party which became a member of Nečas's coalition government until the party split into two factions. The Public Affairs party left the coalition and tried to become closer to President Klaus and later on even to Zeman, without success in either case. For details see Vlastimil Havlík and Vít Hloušek, "Dr Jekyll and Mr Hyde: The Story of the Populist Public Affairs Party in the Czech Republic," Perspectives on European Politics and Society Vol. 15, No. 4 (2014) // DOI: $10.1080 / 15705854.2014 .945254$.

32 Průzkum: S jmenováním Rusnoka souhlasí polovina Čechů, Mladá fronta Dnes (June 28, 2013).

33 Možná budu jako Havel a někoho jen pověrím jednáním o vládě, Právo (July 25, 2013). 
election with the hope that the performance of the government would improve the standing of the Party of Citizens' Rights - "Zemanites". Rusnok's cabinet had been presented as Zeman's cabinet both by its supporters and its opponents since the very first moment of its existence. Such an evaluation is correct in the sense that Zeman was the creator of the cabinet and his views (sometimes more tacitly than explicitly voiced) were fully respected. The cabinet never hesitated to draw its legitimacy from the president and the rhetoric of a "cabinet of experts" was invented by Zeman and used and cherished by both main executive bodies.

It is not without importance for a consideration of the shift within the Czech political system to a semi-presidential model, to compare briefly Zeman's role with similar attempts of his predecessors to build a "president's" cabinet. Generally, the role of president in designing the prime minister and composing the government has been limited in the Czech politics. Both Havel and Klaus respected outcomes of parliamentary elections and followed the patterns of coalitions' formation designed by political parties. Havel in 1996 (after electoral stalemate) only created a new convention to nominate an informateur first to finalize negotiations among the parties before the final composition of ruling coalition was set up. This praxis was later followed by Klaus (and contemplated by Zeman in summer 2013), as well in the cases of unclear parliamentary majority. ${ }^{34}$

There are actually only two exceptions to the rule of very limited engagement of the president in the process of establishment of government: the 1998 cabinet of Josef Tošovský and the 2009-2010 cabinet of Jan Fischer. In the case of Tošovský, the semi-political caretaker government of president Havel played a crucial role in the process of government formation but was in need of compromising with participating political parties as far as the composition of Tošovský cabinet was concerned. However, he was forced by the parliamentary parties to agree with a strict limitation on government duration and agenda. In the case of Fischer's nonpolitical caretaker government, any activity of Klaus in the process of its establishment was successfully blocked by two than strongest political parties Civic and Social Democrats. ${ }^{35}$

Compared to these two attempts, Zeman's role was decisively more prominent even than Havel's influence in 1998. Zeman was not consulting Rusnok's designation with parliamentary parties. He actively shaped both the composition and agenda of the cabinet and played an important role in negotiating a vote of

\footnotetext{
34 Vlastimil Havlík, "Česká republika": 47-48; in: Stanislav Balík and Vlastimil Havlík, eds., Koaliční vládnutí ve střední Evropě (1990-2010) (Brno: muni press, 2011).

${ }^{35}$ Lubomír Kopeček and Vít Hloušek, "Caretaker Governments in Czech Politics: What to do about a Government Crisis," Europe-Asia Studies Vol. 66 (2014) [forthcoming] // DOI: $10.1080 / 09668136.2014 .941700$.
} 
confidence for it. Rusnok's cabinet was formed in a genuinely semi-presidential way.

\section{THE EARLY PARLIAMENTARY ELECTIONS OF 2013 AND THE FALL OF THE "ZEMANITES" PARTY}

The relation between Zeman and the "Zemanites" Party must be investigated as well. SPOZ contributed significantly in the process of nomination of Zeman to presidential candidate by collecting the necessary 50 thousands signatures supporting the nomination. ${ }^{36}$ The campaign for collecting signatures proved to be very successful. Zeman passed the fifty-thousand hurdle as early as late June $2012,{ }^{37}$ and in sum, he was supported by 106,018 signatures of which the Ministry of Interior authorised 82,856 . In the coming campaign, Zeman decided to help the "Zemanites".

We already dealt with the proximity between the party and caretaker cabinet. Many prominent members of the "Zemanites" found a place in the administrative apparatus of the President's Office. Last but not least, Zeman was indirectly engaged in the "Zemanites'" electoral campaign. The motive of the official presidential stamp was used on the billboards of the Party as well as a "coincidental" overlap of President Zeman's travels to different regions of Bohemia, Moravia and Silesia and the campaign activities of the party at the same places. Zeman denied any connection, saying that he was only fulfilling one of his promises to be in direct and frequent contact with the people in the regions. ${ }^{38}$

The culmination of popular dissatisfaction with the performance of Rusnok's cabinet, which, despite its caretaker character, was responsible for a massive replacement of personnel in many key ministries, scandals associated with close collaborators of Zeman, declining public support for Zeman himself and the emergence of new protest parties led to electoral disaster for the Zemanites. A party which dreamed of getting about ten percent of the vote scored with only roughly 75,000 votes ( 1.51 per cent of the vote). Zeman reacted by breaking contacts with the party's top leaders (excluding those employed in his office) and declared that the Party should quit using the nickname "Zemanites" in the future. ${ }^{39}$

Despite the failure of the Zeman-centred electoral strategy, there remained a strong card to play. The active approach of President Zeman to the formation of

\footnotetext{
36 Tomáš Franko, Eva Nováčková, and Jakub Šedo, "Nominace kandidátů, průběh a výsledky voleb": 39; in: Jakub Šedo, ed., České prezidentské volby v roce 2013 (Brno: Centrum pro studium demokracie a kultury, 2013).

37 Mám tisíc podpisů, chci být prezidentem, Blesk (June 27, 2013).

38 TV Prima (September 1, 2013) // http://www.zemanmilos.cz/cz/clanky/rozhovor-prezidentarepubliky-pro-porad-tv-prima-partie.htm.

39 Radiožurnál (February 16, 2014) // http://www.zemanmilos.cz/cz/clanky/hovory-z-lan-280022.htm.
} 
Rusnok's interim cabinet was seen by many observers of the Czech political scene as a blueprint for Zeman's behaviour in the process of the formation of the government after the election. The verbal strategy of Zeman seemed to confirm this observation. On the one hand, Zeman repeatedly declared that he would designate to the position of prime minister the person selected by the victorious Social Democracts. On the other hand, his antipathy towards the chair of the party, Sobotka, dated to the 2003 indirect presidential election in which Sobotka and some of his political colleagues inside the party presumably did not vote for Zeman. Publically demonstrated close ties between Zeman and the faction led by Hašek became evident just after the parliamentary election internal feud in the Social Democratic Party concerning the name of the upcoming prime minister. Literarily at the same time that Sobotka commented on the outcome of the election on the screens of Czech TV, Hašek and a couple of other leading Social Democratics visited Zeman in Lány. The so-called Lány Meeting was meant to be kept beyond the public eye as well as the eyes of Sobotka's faction. It was, however, soon disclosed, and somewhat paradoxically it helped Sobotka to maintain his leading position in the team of Social Democratic negotiators in a new coalition with ANO 2011 and the Christian Democrats. The exact content of the meeting is still not publically known even today. Most likely the politicians talked about the situation inside the Social Democratic Party after a not very convincing electoral performance. ${ }^{40}$ Zeman's prestige suffered a lot because of the Lány meeting. According to the regular poll held by the CVVM, Zeman was trusted by 51 per cent of respondents in October and only 39 percent in November 2013. Public opinion obviously interpreted the meeting as an attempt by Zeman to gain personal influence in the Czech Social Democratic Party and was not welcomed. ${ }^{41}$

Despite this tactical "loss", Zeman continued to play an assertive role. His new tactic to enter the debate on the composition of government was to criticize some of the emerging nominees for ministerial positions for their lack of expertise. This tactic was broader than being just directed at the Social Democratic Party. Zeman tried to expand his say beyond the Social Democratic limits since the name that became the symbol of such activity was that of ANO 2011 candidate for minister of defense Martin Stropnický. Zeman again stretched the meaning of the constitution to say:

\footnotetext{
40 Some quarter of a year after the Lány Meeting, Zeman described the session as being organized by Hašek and that the content of debate was related to Zeman's $69^{\text {th }}$ birthday and to the bad electoral returns of the Social Democratic Party which obtained only slightly more than 20 per cent of the vote (according to some earlier pre-election polls, the party could count even on 30 per cent). 41 Lánská schůzka připravila Zemana o popularitu, Hospodářské noviny (December 3, 2013) // http://archiv.ihned.cz/c1-61378160-lanska-schuzka-pripravila-zemana-o-popularitu.
} 
As you know well, the government is appointed by the president according to the proposal of the prime minister. As far as the word proposal is concerned, it has an absolutely clear meaning in the colloquial Czech language. The proposal is not something you must accept automatically. In the case it was so, it would have interesting consequences for commercial as well as for marital relations. ${ }^{42}$

Zeman's rhetoric concerning candidates with a given lack of expertise was again very strong; however, the result was zero. The real process of government composition remained in the hands of the coalition parties and prime minister Sobotka. Zeman's ironical remarks about him and some parts of the governmental program declaration could hardly disguise the fact that Zeman had lost again.

Zeman was not the first to demonstrate a tendency to block the nomination of the candidate. Klaus refused to appoint David Rath in 2005 before he left the office of chair of the Czech Chamber of Medical Doctors. Klaus expressed his objection to a particular candidate again in 2007 criticizing the Austrian citizenship of minister of foreign affairs Schwarzenberg. In this case, however, Klaus did not postpone the nomination. To some extent we can say that Zeman used some precedents without directly using this argument in political discussion.

In sum, Zeman has constantly been attempting to become an active, driving force in the Czech political scene. After a "prelude" of dispute over envoys' nomination, he played a very strong card in the process after the fall of Nečas's cabinet and the formation of Rusnok's one. Rusnok's cabinet embodied Zeman's idea about how the president-related government should look both in terms of program and personal composition. Together with the involvement of some members of Rusnok's cabinet in the "Zemanites" Party campaign for early election, this should safeguard parliamentary relevance and perhaps even governmental participation for a party that would express and support the political line of the president. The failures of Rusnok and the Zemanites did not prevent Zeman from using a very assertive rhetoric after elections. However the situation of the postelectoral political scene, Sobotka's tiny victory inside the Social Democratic Party and the rising star of Babiš's ANO 2011 effectively shrunk the space for Zeman's manoeuvers. Zeman's attempt to build a power base proved unsuccessful after the 2013 elections.

Without strong allies, encircled by adversarial attitudes on forming the new coalition cabinet, and facing a decline of popularity, Zeman tacitly decided to abandon the strategy of accruing personal power, at least for the time being.

42 Press conference (January 10, 2014) // http://www.zemanmilos.cz/cz/clanky/tiskova-konferenceprezidenta-republiky.htm. 


\section{CONCLUSION}

The main aim of the paper was to discuss the importance of formal and informal factors in the definition of a semi-presidential political system. The second aim of the paper was to assess whether the Czech Republic is undergoing a change of political system from a parliamentary to a semi-presidential model of democracy.

We can conclude from the analysis of Zeman's first year of political activities that all his attempts failed so far, and despite Zeman's rhetorical strength, the other political actors developed successful strategies to defend their powers and prerogatives. In the medium term perspective, Zeman failed to build his power base on Rusnok and the "Zemanites". However, if one looks back at the period of Rusnok's cabinet, it is clear that Zeman executed exactly what we called real power in the working definition of semi-presidentialism.

After the 2013 election, Zeman failed to maintain his power vis-à-vis the new full political cabinet. The Czech Republic thus remained a political system of parliamentary democracy according to our working definition of semipresidentialism. As can be seen from the analysis of Zeman's attempts at increasing power and responses to these attempts by the remaining parts of the Czech political elite, the head of state is as powerful or as weak as the political parties. Once the parties in government (or parties preparing the coalition governance) act in accord, the role of the president remains limited. Constitutional distribution of power has remained intact after introduction of the direct election. Thus, the Czech political system is not heading in the direction of Romania or France. Neither, however, is the Czech case so clearly in favour of a parliamentary regime as in the case of Slovakia, where the presidential constitutional powers were limited when the direct elections were introduced in 1999. The Czech case thus shows well the vulnerability of the balance of power within political systems with clearly prevailing parliamentary features and directly elected president. Similarly to Slovenia, Poland, or Lithuania, the functioning of the political system depends very much on certain informal factors such as a president's personality, the stability and coherence of the party system, and the likes and dislikes of public opinion.

With respect to the aforementioned, a discussion about the very concept of semi-presidentialism must be revisited. The example of the Czech Republic shows how much the real distribution of roles inside the executive body depends on the current distribution of power. The position of Zeman during the heyday of Rusnok's cabinet closely resembled a highly presidentialised semi-presidentialism; and Zeman's role after Sobotka's coalition government had obtained a vote of confidence is far below the scenario of balanced presidential-prime ministerial semi- 
presidentialism. If there is anything to be learned from the previous analysis in regard to the conceptual delimitation of semi-presidentialism, it is a focus on the element of the distribution of power inside the executive body that creates the edge between real semi-presidentialism and the parliamentary regimes with a mere direct election of the head of state. The category of "real impact", as related to power of the president, used as the third element of our Elgie-inspired working definition of semi-presidentialism, is the crucial issue still to be investigated empirically and considered in a theoretical debate. Attention should especially be paid to the relations between the president and prime minister/government and the extent to which a president can steer agenda setting, personnel composition, and in some cases even the policy choices of the cabinet. These are variables to be added to attempts to measure presidential powers as well as to conceptual definitions of the models of political systems in a more systematic way.

The second lesson to be learned from the recent Czech development is the relative instability of relations between a president and a government or a prime minister in terms of political power, influence, and impact. Here the scholarly debate can follow the findings of Margit Tavits, ${ }^{43}$ who emphasized changing political opportunities as the main source of the dynamics of presidential activism vis-à-vis the changing power of the prime minister, government, and political parties. This is not surprising, especially in the countries (such as the Czech Republic) in which some important feature of constitutional delimitation of the role of president changed and the new informal rules are yet to be established. Since the process of stabilization of informal rules depends a lot on unique personal configurations president-prime minister, it can take time and it can be a factor assisting in maintaining uncertainty concerning the exact determination of a regime type.

Single country studies aimed at collecting detailed evidence should be conducted before a scholar embarks down the route of generalization. This article is an attempt to contribute to analysis of the new development in the Czech political scene which, as demonstrated, raises interesting arguments for re-considering the role of the president in the political process as well as the very concept of semipresidentialism.

\section{BIBLIOGRAPHY}

1. Beach, Derek, and Rasmus Brun Pedersen. Process-Tracing Methods: Foundations and Guidelines. Ann Arbor: The University of Michigan Press, 2003.

\footnotetext{
${ }^{43}$ Margit Tavits, Presidents with Prime Ministers (Oxford: Oxford University Press, 2009).
} 
2. Checkel, Jeffrey T. "Process Tracing": 114-127. In: Audie Klotz and Deepa Prakash, eds. Qualitative methods in international relations: a pluralist guide. London: Palgrave Macmillan, 2008.

3. Cheibub, José Antonio. Presidentialism, Parliamentarism and Democracy. Cambridge: Cambridge University Press, 2007.

4. Cheibub, José Antonio, Zachary Elins, and Tom Ginsburg. "Beyond Presidentialism and Parliamentarism." British Journal of Political Science Vol. 44, No. 3 (2014): 515-544 // DOI: 10.1017/S000712341300032X.

5. Duverger, Maurice. "A New Political System Model: Semi-Presidential": 142149. In: Arend Lijphart, ed. Parliamentary versus Presidential Government. Oxford: Oxford University Press, 1992.

6. Elgie, Robert, and Sophia Moestrup, eds. Semi-Presidentialism in Central and Eastern Europe. Manchester: Manchester University Press, 2008.

7. Elgie, Robert. "Semi-presidentialism: An Increasingly Common Constitutional Choice": 1-20. In: Robert Elgie, Sophia Moestrup, and Yu-Shan Wu, eds. Semi-Presidentialism and Democracy. Basingstoke: Palgrave MacMillan, 2011.

8. Elgie, Robert. "The Politics of Semi-Presidentialism": 1-21. In: Robert Elgie, ed. Semi-Presidentialism in Europe. Oxford: Oxford University Press, 1999.

9. Franko, Tomáš, Eva Nováčková, and Jakub Šedo. "Nominace kandidátů, průběh a výsledky voleb": 37-51. In: Jakub Šedo, ed. České prezidentské volby $v$ roce 2013. Brno: Centrum pro studium demokracie a kultury, 2013.

10. Havlík, Vlastimil, and Vít Hloušek. "Dr Jekyll and Mr Hyde: The Story of the Populist Public Affairs Party in the Czech Republic." Perspectives on European Politics and Society Vol. 15, No. 4(2014): 552-570 //

DOI: $10.1080 / 15705854.2014 .945254$.

11. Havlík, Vlastimil. "Česká republika": 39-90. In: Stanislav Balík and Vlastimil Havlík, eds. Koaliční vládnutí ve střední Evropě (1990-2010). Brno: muni press, 2011.

12. Kopeček, Lubomír, and Josef Mlejnek. "Different Confessions, Same Sins? Václav Havel and Václav Klaus as Czech Presidents": 31-75. In: Vít Hloušek, ed. Presidents above parties? Presidents in Central and Eastern Europe, Their Formal Competencies and Informal Power. Brno: muni press, 2013.

13. Kopeček, Lubomír, and Vít Hloušek. "Caretaker Governments in Czech Politics: What to do about a Government Crisis." Europe-Asia Studies Vol. 66 (2014) [forthcoming] // DOI: 10.1080/09668136.2014.941700.

14. Krašovec, Alenka, and Damjan Lajh. "The Chameleonic Character of the Slovenian Presidents of the Republic": 143-165. In: Vít Hloušek, ed. 
Presidents above parties? Presidents in Central and Eastern Europe, Their Formal Competencies and Informal Power. Brno: muni press, 2013.

15. Krouwel, André. "Measuring presidentialism of Central and Eastern European Countries." Working Papers Political Science (Amsterdam, Vrije Universiteit) No. 02/2003: 1-22 // http://www.fsw.vu.nl/en/Images/Globalisation,\%20Neoliberalism\%20and\%20the\%20Employment\%20Question_tcm31-42728.pdf.

16. Kysela, Jan, and Zdeněk Kühn. "Presidential Elements in Government: The Czech Republic." European Constitutional Law Review Vol. 3, No. 1 (2007): 91-113 // DOI: 10.1017/S1574019607000910.

17. Mahoney, James. "Qualitative Methodology and Comparative Politics." Comparative Political Studies Vol. 40, No. 2 (2007): 122-144 // DOI: $10.1177 / 0010414006296345$.

18. Millard, Frances. "Presidents and Democratization in Poland: The Roles of Lech Wałęsa and Aleksander Kwaśniewski in Building a New Polity." Journal of Communist Studies and Transition Politics Vol. 16, No. 3 (2000): 39-62 // DOI: $10.1080 / 13523270008415440$.

19. Musilová, Markéta, and Jakub Šedo. "Diskuse o zavedení prímé volby prezidenta v České republice a její schválení": 9-35. In: Jakub Šedo, ed. České prezidentské volby $v$ roce 2013. Brno: Centrum pro studium demokracie a kultury, 2013.

20. Pasquino, Gianfranco. "Semi-presidentialism: A Political Model at Work." European Journal of Political Research Vol. 31, No. 1 (1997): 128-137 // DOI: 10.1111/1475-6765.00309.

21. Sartori, Giovanni. "Concept Misformation in Comparative Politics." The American Political Science Review Vol. 64, No. 4 (1970): 1033-1053 // DOI: $10.2307 / 1958356$.

22. Sartori, Giovanni, Comparative Constitutional Engineering: An Inquiry into Structures, Incentives and Outcomes. Basingstoke: MacMillan, 1994.

23. Sedelius, Thomas, and Sten Berglund. "Towards Presidential Rule in Ukraine: Hybrid regime Dynamics under Semi-Presidentialism." Baltic Journal of Law \& Politics Vol. 5, No. 1 (2012): 20-45 // DOI: 10.2478/v10076-012-0002-2.

24. Siaroff, Alan. "Comparative presidencies: The inadequacy of the presidential, semi-presidential and parliamentary distinction." European Journal of Political Research Vol. 42, No. 3 (2003): 287-312 // DOI: 10.1111/1475-6765.00084.

25. Tavits, Margit. Presidents with Prime Ministers. Oxford: Oxford University Press, 2009. 